\title{
PENGARUH PEMBERIAN AIR REBUSAN DAUN JAMBU BIJI TERHADAP KADAR GLUKOSA DARAH PADA PENDERITA DIABETES MELLITUS TIPE II DI WILAYAH KERJA PUSKESMAS PEKKABATAKABUPATEN POLEWALI MANDAR
}

\begin{abstract}
Umi Hani
Latar Belakang: Penderita diabetes mellitus di dunia semakin meningkat setiap tahun, pada tahun 1994 berjumlah 150 juta orang dan pada tahun 2010 berjumlah 279,3 juta dan diperkirakanTahun 2020 berjumlah 300 juta. Pada tahun 2011 diperkirakan 366 juta orang di seluruh dunia menderita diabetes melitus tipe 2.Fungsi 2.Estimasi Terakhir, ada 382 juta orang yang hidup dengan diabetes di Dunia pada tahun 2013. Diperkirakan 382 juta orang, 175 juta di antaranya belum didiagnosis sehingga terancam oleh tumbuh semakin tanpa komplikasi tidak sadar dan tanpa pencegahan.

Jenis penelitian ini adalah desain penelitian eksperimental "true experiment" yaitu penelitian yang dilakukan eksperimen nyata. Ukuran sampel dalam penelitian ini adalah jumlah 10 pasien dengan diabetes tipe II yang diberi daun jambu biji air rebusan pada saat penelitian di mana pasien di rumah Puskesmas Takkatidung desa Pekkabata Polewali Mandar tahun 2017. Teknik pengambilan sampel dalam penelitian ini adalah total teknik pengambilan sampel, yaitu pengambilan sampel total populasi seluruhnya agar mendapatkan sampel 10 orang diberi rebusan air daun jambu biji.
\end{abstract}

Kata kunci: eksperimental, glukosa darah acak sebelum dan sesudah pemberian air rebusan daun jambu biji, daun jambu rebus

This type of research is experimental research design "true experiment" that is research conducted experiments for real. The sample size in this study is the number of 10 patients with type II diabetes are given water boiled guava leaves at the time of the study in which patients do at home Takkatidung village Puskesmas Pekkabata Polewali Mandar Year 2016. Sampling Techniques in the study was total sampling technique, which is sampling the total of the population entirely in order to get a sample of 10 people were given water decoction of guava leaves. Statistic test that is used in this study aalah Mc. Nemar in this study is very clear there is influence between the provision of water boiled guava leaves on blood sugar levels as where the effect is a decrease in blood sugar after drinking water decoction of guava leaf which is evidenced in the significant value, $031<\alpha=0.05$, which means that Ho rejected $\mathrm{H} 1$ accepted.

Conclusion : There Effect of water decoction of guava leaves on blood glucose levels in people with type II diabetes mallitus in Puskesmas Pekkabata Polewali Mandar.

Suggestion : based on the results of the study are expected to society, especially people with diabetes to be more active again looking for information about herbs that can lower blood glucose levels to return to normal

Keywords : experimental, random blood glucose before and after the administration of the water decoction of guava leaves, boiled guava leaves

Bibliography : 16 Books + 2 Internet ( 2006-2016)

\section{PENDAHULUAN}

Penderita diabetes mellitus di dunia meningkat setiap Tahun, pada Tahun 1994 sebesar 150 juta penderita dan pada Tahun 2010 sebesar 279,3 juta dan diperkirakanTahun 2020 sebesar 300 juta. Tahun 2011 diperkirakan 366 juta penduduk dunia menderita diabetes melitus tipe 2.Estimasi terakhir IDF, terdapat 382 juta orang yang hidup dengan diabetes di Dunia pada Tahun 2013. Diperkirakan dari 382 juta orang tersebut,175 juta diantaranya belum terdiagnosis sehingga terancam berkembang progresif menjadi komplikasi tanpa disadari 
dan tanpa pencegahan(International Diabetes

Federation (IDF), 2013).

Kematian di Asia Tenggara paling banyak disebabkan oleh penyakit tidak menular salah satunya adalah Diabetes Mellitus (DM). DM dikenali sekitar 1500 tahun sebelum Masehi oleh bangsa Mesir sebagai sebuah keadaan dimana seseorang buang air kecil berlebihan dan mengalami penurunan berat badan. Aretaeus (80-138 SM), seorang ilmuwan Yunani menyatakan bahwa urin orang yang mengidap DM terasa manis, sampai pada 1776 Matthew Dobson mengoreksi bahwa yang terjadi adalah naiknya konsentrasi glukosa pada urin penderita DM. Sejak terdiagnosis DM disebabkan oleh kekurangan insulin, penyakit ini menjadi sangat progresif. Sekalipun DM dihubungkan dengan penurunan harapan hidup, penderita DM diharapkan dapat menjalani kehidupan yang aktif dan produktif untuk beberapa tahun kedepan setelah diagnosis ditegakkan. Prevalensi penyakit DM pada tiga sampai empat dekade belakangan ini telah meningkat secara dramatis di berbagai belahan dunia dan menempatkan DM menjadi salah satu kondisi medis serius yang harus dihadapi(Polonsky, 2012).

Indonesia terdapat sekitar 8.426 .000 orang menderita DM tipe 2. Populasi penderita diabetes mellitus (DM) di Indonesia saat ini menduduki peringkat kelima terbanyak di dunia. Berdasarkan data IDF Diabetes Atlas, pada tahun 2013 penderita DM di Tanah Air mencapai 8.554.155 orang, bahkan angka tersebut akannaik pada tahun 2014 hingga mencapai 9,1 juta orang(Prof. Dr. Achmad Rudijanto,Perkeni 2015).
Pada tahun 2013, proporsi penduduk Indonesia yang berusia $\geq 15$ tahun dengan DM adalah 6,9 \%. Prevalensi diabetes yang terdiagnosis dokter tertinggi terdapat di DI Yogyakarta (2,6\%), DKI Jakarta (2,5\%), Sulawesi Utara $(2,4 \%)$, dan Kalimantan Timur $(2,3 \%)$. Prevalensi diabetes yang terdiagnosis dokter atau berdasarkan gejala, tertinggi terdapat di Sulawesi Tengah $(3,7 \%)$, Sulawesi Utara $(3,6 \%)$, Sulawesi Selatan $(3,4 \%)$ dan Nusa Tenggara Timur (3,3\%). Prevalensi DM di Indonesia beranjak naik dari tahun ke tahun. Penderita yang terkena bukan hanya berusia senja, namun banyak pula yang masih berusia produktif. Prevalensi DM berdasarkan diagnosis dokter dan gejala meningkat sesuai dengan bertambahnya umur, namun mulai umur $\geq 65$ tahun cenderung menurun. Prevalensi DM pada perempuan cenderung lebih tinggi dari pada laki-laki, di perkotaan cenderung lebih tinggi dari pada di perdesaan, serta cenderung lebih tinggi pada masyarakat dengan tingkat pendidikan tinggi dan dengan kuintil indeks kepemilikan tinggi (Kemenkes, 2013).

DM menempati peringkat ke lima dari sepuluh penyebab utama kematian di Makassar tahun 2007 dengan jumlah sebanyak 65 kasus. Berdasarkan data dari Dinas Kesehatan Kota Makassar, angka kejadian penyakit diabetes mellitus pada tahun 2011, yaitu 5700 kasus.Pada tahun 2012 angka kejadian kasus DM (diabetes mellitus) meningkat menjadi 7000 kasus.Kota Makassar terdiri dari 14 kecamatan. Jika dilihat berdasarkan jumlah kasus DM (diabetes mellitus) per kecamatan pada tahun 2012, didapatkan tiga kecamatan 
yang memiliki angka kejadian DM (diabetes mellitus) tertinggi, yaitu Kecamatan Makassar sebanyak 1076 kasus, Kecamatan Tamalate sebanyak 910 kasus, dan Kecamatan Biring Kanaya sebanyak 700 kasus.(Dinas Kesehatan 2014)

Menurut data dari RSU Polewali kabupaten Polewali Mandar 2011 penderita penyakit Diabetes Mellitus merupakan urutan ke tiga dengan penyakit rawat jalan terbesar yaitu sekitar 678 orang. Hasil studi penjajakan di Wilayah puskesmas Pekkabata Kabupaten Polewali Mandar Tahun 2015 didapatkan data kunjungan sebanyak 54 kasus. Pada tahun 2014 mengalami peningkatan kunjungan 82 kasus. Sedangkan kasus DM (Diabetes Mellitus) di Kabupaten Polewali Mandar yaitu 1423 kasus. Hasil wawancara dari 5 penderita diabetes mellitus di Desa Takkatidung mengatakan mereka tidak mengetahui pengaruh pemberian air rebusan daun jambu biji terhadap penurunan gula darah .

Berdasarkan hasil penelitian yang dilakukan oleh Maharani tahun 2013 di kota semarang pada 28 orang dengan diabetes mellitus tipe II, setelah diberikan air rebusan daun jambu biji selama seminggu berturutturut. Sebanyak $600 \mathrm{ml}$ setiap pagi dan sore hari, didapatkan hasil penurunan gula darah sewaktu (rata-rata 232,07 $\mathrm{mg} / \mathrm{dl}$ menjadi $192,21 \mathrm{mg} / \mathrm{dl}$.

Sebagai tanaman yang cukup potensial, tentunya jambu biji sudah sepatutnya untuk dikembangkan. Hasilnya selain dapat digunakan sebagai penganekaragaman menu rakyat, juga mempunyai prospek penting sebagai bahan dasar industri. Maka tidak terlalu bila di katakan bahwa, tanaman jambu biji ini jika di kembangkan akan menjadi tanaman komersial di bidang kesehatan.Tanaman jambu biji biasa tumbuh di daerah yang dingin, tetapi ada juga ada juga jambu biji yang hidup di daerah tropis. Jambu biji merupakan suatu tumbuhan tanaman yang memiliki ketinggian mencapai 2 meter, berwarna hijau dengan daging buah yang berwarna putih berasa manis, buah jambu biji di kenal banyak mengandung vitamin C. (Paul Apt,2015)

Tanaman yang dikenal sehari-hari, dikenal dengan jambu biji, kulit luar nya biasanya terlihat berwarna hijau kekuning-kuningan dan bila dibelah maka isi dalam nya nampak berwarna merah dengan biji-biji kecil yang berada ditegah buah ini maka dari itu buah ini di sebut dengan jjambu biji merah. buah jambu bii tersebut mempunyai kandungan kalori vitamin A,B1,C,Kalsium. zat besi dan air yang bagus untuk menjaga kekebalan tubuh karena mengandung vitamin $C$ yang banyak. selain itu, jambu merah biji dapat digunakan untuk kepentingan pengobatan tradisional atau digunakan sebagai untuk mengobati beberapa penyakit seperti diabetes melitus dengan cara mengkonsumsi buah jambu biji merah baik dengan cara dimakan langsung atau dijus terlebih dahulu. itu semua berkat kandungan gula alamiah yang ada di dalam kandungan itu.khasiat dari daun jambu biji untuk diabetes, nutrisi dan metabolisme dan setelah meminumnya dapat menghambat enzim ALPHA glukosidase, pengendalian kadar gula darah penting untuk orang dengan diabetes atau pre diabetes sehingga tidak membutuhkan komplikasi. (Eridasuryani,2012) 
Daun merupakan salah satu organ tumbuhan yang tumbuh dari batang, umumnya berwarna hijau (mengandung klorofil) dan terutama berfungsi sebagai penangkap energi dari cahaya matahari melalui fotosintesis. Daun merupakan organ terpenting bagi tumbuhan dalam melangsungkan hidupnya karena tumbuhan adalah organisme autotrof obligat, ia harus memasok kebutuhan energinya sendiri melalui konversi energi cahaya menjadi energi kimia. (blogspot.com, 2011)

Daun jambu biji sangat sehat karena dapat mencegah kemungkinan terkena diabetes. Keringkan daun jambu biji dan hancurkan. Rebus dalam air panas seperti teh untuk mendapatkan semua bahan esensial dari daun jambu biji dan konsumsi air rebusannya. Daun jambu biji dapat mencegah diabetes dan

\section{METODE PENELITIAN}

\section{Jenis dan Metode Penelitian}

Desain penelitian
keseluruhan dari perencanaan untuk
menjawab pertanyaan penelitian dan
mengantisipasi beberapa kesulitan yang
mungkin timbul selama proses penelitian.
Desain penelitian merupakan bentuk
rancangan yang digunakan dalam
melakukan prosedur penelitian. (Azis

Alimul Hidayat, 2008)

Berdasarkan tujuan penelitian desain penelitian pada penelitian ini adalah “True eksperiment" (Notoatmodjo, 2010).

\section{Lokasi dan Waktu Penelitian}

Penelitian ini akan dilakukan mulai bulan 3 sampai bulan 4 yaitu pada bulan Januari-April 2017 di desa takkatidung Kabupaten Polewali Mandar yang tentunya mengurangi kadar gula darah pada penderita diabetes.( Boldsky,2012)

Jambu biji (Psidium gujava) adalah tumbuhan yang mudah tumbuh dimana saja dan tanpa mengenal musim selalu dapat tumbuh dan berbuah lebat. Tanaman jambu biji banyak terdapat di Desa Takkatidung dan daun jambu biji belum banyak dimanfaatkan dikarenakan kurangnya informasi mengenai manfaat daun jambu biji. Warga desa Takkatidung banyak yang tidak mengetahui bahwa daun jambu biji dapat menurunkan kadar glukosa darah.

Berdasarkan fenomena diatas peneliti merasa tertarik untuk mengetahui tentang"bagaimana pengaruh pemberian air rebusan daun jambu biji terhadap kadar glukosa darah pada penderita diabetes mellitus tipeII di Wilayah Kerja Puskesmas Pekkabata Kabupaten Polewali Mandar”.

dilaksanakan setelah mendapat izin dari pihak yang terkait.

\section{Populasi dan Sampel}

Populasi

Populasi yang dipakai dalam penelitian ini adalah keseluruhan penderita diabetes yang berada di wilayah kerja Puskesmas Pekkabata Kabupaten Polewali Mandar sebanyak 10 pasien.

Sampel

Kriteria Insklusi adalah karakteristik sampel yang dapat dimasukkan atau yan layak untuk dijadikan sampel.

Kriteria insklusi dalam penelitian ini adalah : 
1. Pasien DM (Diabetes Mellitus) bersedia untuk diteliti

2. Pasien diabetes mellitus yang tidak pernah mengkonsumsi obat antidiabetik sama sekali atau obat herbal lainnya

Kriteria Eksklusi

Kriteria eksklusi adalah karakteristik sampel yang tidak layak untuk dijadikan sampel.
1. Pasien bukan DM tipe II dan tidak bersedia

2. Pasien diabetes mellitus yang mengkonsumsi obat antidiabetik sama sekali atau obat herbal lainnya

\section{HASIL DAN PEMBAHASAN}

\section{Hasil Penelitian}

Analisa Univariat

Distribusi glukosa darah responden sebelum pemberian air rebusan daun jambu biji

Tabel 4.1 Distribusi glukosa darah responden sebelum pemberian air rebusan daun jambu biji 10 lembar

\begin{tabular}{|l|l|l|l|l|l|l|}
\hline \multirow{2}{*}{$\begin{array}{l}\text { Glukosa darah } \\
\text { sewaktu (GDS) }\end{array}$} & \multicolumn{2}{|l|}{ Normal } & \multicolumn{2}{l|}{ Tidak normal } & \multicolumn{2}{c|}{ Total } \\
\cline { 2 - 7 } & F & $\%$ & F & $\%$ & N & $\%$ \\
\hline $\begin{array}{l}\text { Sebelun } \\
\text { pemberian air } \\
\text { rebusan daun } \\
\text { jambu biji }\end{array}$ & 0 & 0 & 10 & 100 & 10 & 100 \\
\hline
\end{tabular}

\section{Sumber : Data Primer 2017}

Dari tabel 4.1 terlihat bahwa dari 2

jumlah responden, karakteristik glukosa darah sewaktu (GDS) sebelum pemberian air rebusan daun jambu biji terdapat $0(0 \%)$ yang normal dan yang tidak normal $10(100 \%)$ responden.

\section{Tabel 4.2}

Distribusi glukosa darah responden setelah pemberian air rebusan daun jambu biji 10 lembar

\begin{tabular}{|l|l|l|l|l|l|l|}
\hline \multirow{2}{*}{$\begin{array}{l}\text { Glukosa darah } \\
\text { sewaktu (GDS) }\end{array}$} & \multicolumn{2}{|l|}{ Normal } & \multicolumn{2}{l|}{ Tidak normal } & \multicolumn{2}{l|}{ Total } \\
\cline { 2 - 7 } & F & $\%$ & F & $\%$ & N & $\%$ \\
\hline $\begin{array}{l}\text { Setelah } \\
\text { pemberian air } \\
\text { rebusan daun } \\
\text { jambu biji }\end{array}$ & 4 & 40 & 6 & 60 & 10 & 100 \\
\hline
\end{tabular}

\section{Analisa Bivariat}

Analisa Bivariat dalam penelitian ini adalah untuk mengetahui pengaruh pemberian air 
rebusan gula darah terhadap dula darah pada penderita DM tipe II di Puskesmas Pekkabata Tabel 4.3 Hasil uji statistic Mc.Nemar
Kab. Polewali Mandar dimana uji stratistic yang digunakan adalah uji Mc. Nemar.

\begin{tabular}{|c|c|c|}
\hline Mc.Nemar & Value & Exact sig (2-sided) \\
\cline { 3 - 3 } & &, 031 \\
\hline N of Valid Cases & 10 & \\
\hline
\end{tabular}

\section{Sumber : Data Primer}

Dari tabel 4.2 uji Mc.Nemar di atas dapat dilihat bahwa nilai signifikasi adalah,031 yang berarti bahwa nilai itu lebih kecil daripada nilai $\alpha=0,05$

\section{PEMBAHASAN}

Sesuai dengan teori menurut Nurrahmani(2012) dan Wijoyo (2010) mengatakan ada beberapa faktor yang dapat mempengaruhi kadar glukosa dara diantaranya kurang sensitifnya jaringan tubuh terhadap insulin karena jumlah atau aktivitas reseptor insulin berkurang pada sel, pola makan yang berlebihan menyebabkan kadar glukosa dalam darah meningkat karena keterbatasan sel $\beta$ pancreas untuk mensekresi insulin, obesitas mengakibatkan lemak yang berlebihan hal ini akan menyebabkan resistensi terhadap insulin, faktor genetik dapat menyebabakan diabetes mellitus karena diwarisinya gen penyebab diabetes mellitus, bahan-bahan kimia dan obatobatan tertentu dapat menyebabkan radang pankreas sehingga pankreas tidak berfungsi secara optimal. Faktor selanjutnya yang mempengaruhi kadar glukosa darah adalah stress. Stres menyebabkan tubuh menghasilkan hormon-hormon racun, kondisi stress yang terusmenerus akan menyebabkan terjadi kandungan racun yang melimpah di dalam tubuh. Inilah yang kemudian mengacaukan seluruh metabolisme tubuh. Sensitivitas insulin pun terganggu dan menyebabkan terjadinya diabetes mellitus (Susilo, 2011)

Sesuai dengan teori yang dikemukakan oleh Anastasia Bangun (2007) pada penelitian kemotaksonomi bahwa dalam daun jambu biji mengandung senyawa tanin yang berfungsi sebagai penghambat $\alpha$ - glukosidase yang bermanfaat untuk menunda absorpsi glukosa setelah makan sehingga menghambat kondisi hiperglikemia postprandial. Kalsium pada daun jambu biji mampu menaikkan produksi sel-sel $\beta$ pankreas untuk menghasilkan insulin. Kalsium bereaksi dengan menstimulus pembebasan insulin dari sel beta pada pulau langerhans pankreas (Simon, 2008).

Berdasarkan hasil uji t-test independent didapatkan nilai $p$-value sebesar $0,014<\alpha$ $(0,05)$, maka dapat disimplkan bahwa ada perbedaan yang signifikan kadar glukosa darah puasa sesudah perlakuan antara kelompok intervensi dan kontrol pada penderita diabetes mellitus tipe II di Desa Leyangan Kec. Ungaran 
Timur Kab. Semarang. Ini juga berarti bahwa ada pengaruh yang signifikan pemberian air rebusan daun jambu biji (Psidium guajava) terhadap kadar glukosa darah puasa pada penderita diabetes mellitus tipe II di Desa Leyangan Kec. Ungaran Timur, Kab. Semarang. Mean difference kadar glukosa darah puasa responden kelompok intervensi setelah diberikan air rebusan daun jambu biji (Psidium guajava) sebesar 39,857 mg/dl.

Berdasarkan uraian yang dijelaskan diatas dapat disimpulkan bahwa pemberian air rebusan daun jambu biji merupakan suatu metode herbal yang dapat dilakukan untuk pengobatan diabetes mellitus.

Dari hasil pengukuran yang dilakukan sebelum pemberian air rebusan daun jambu biji terdapat $0(0 \%)$ responden yang glukosa darahnya normal dan yang tidak normal sebanyak 10 (100\%). Sedangkan setelah pemberian air rebusan daun jambu biji terdapat $6(60 \%)$ responden yang glukosa darahnya normal dan yang tidak normal sebanyak 4 (40\%) responden.

Maka dapat disimpulkan bahwa ada peningkatan untuk kategori normal setelah pemberian air rebusan daun jambu biji dari 0 responden menjadi 6 responden, jadi terdapat 6 orang yang tadinya sebelum pemberian air rebusan daun jambu biji gula darahnya tidak normal maka setelah pemberian air rebusan daun jambu biji glukosa darahnya menjadi normal. Yang mana hal ini berarti ada pengaruh pemberian air rebusan daun jambu biji terhadap penurunan kadar glukosa darah.
Dalam penelitian ini setelah dilakukan uji statistic dengan menggunakan uji Mc. Nemar maka didapatkan nilai signifikasi 0,031 yang berarti lebih kecil dari $\alpha=0,05$ yang berarti bahwa ada perbedaan yang bermakna antara glukosa darah sebelum pemberian air rebusan daun jambu biji 10 lembar dan setelah pemberian air rebusan daun jambu biji maka dengan ini hipotesis Ho ditolak dan hipotesis Ha di terima yan berarti ada pengaruh pemberian air rebusan daun jambu biji terhadap penurunan kadar glukosa darah pada penderita diabetes mellitus tipe II di Puskesmas Pekkabata Kabupaten Polewali Mandar .

Hal ini sejalan dengan pernyataan yang mengatakan kandungan yang terdapat di dalam daun jambu biji yaitu tanin dan kalsium. Tanin adalah zat pahit polifenol yang sangat baik dan cepat mengikat protein. Daun jambu biji (Psidium guajava) adalah herbal yang bermanfaat sebagai penormal fungsi kelenjar pankreas dengan efek farmakologis memperlancar sistem sirkulasi darah dalam membantu menormalkan fungsi pankreas dalam mengatasi diabetes mellitus, sehingga semakin tinggi /banyak daun jambu biji dapat mempengaruhi kandungan yang terdapat didalamnya (Waid,2011).

Sehingga hasil dari penelitian ini yaitu 10 daun jambu biji dari hasil rebusan lebih efektif menurunkan kadar gula darah di bandingkan penelitian terdahulu yang menggunakan 7 lembar daun jambu di karenakan teori mengatakan semakin banyak daun jambu biji semakin banyak kandungan yang ada didalamnya . 


\section{KESIMPULAN DAN SARAN}

\section{Kesimpulan}

Berdasarkan pengambilan data sebelum pemberian air rebusan daun jambu biji di dapatkan 10 (100\%) responden gula darahnya tidak normal yaitu rata - rata $\geq 200$ $\mathrm{mg} / \mathrm{dl}$.

Berdasarkan data sesudah pemberian air rebusan daun jambu biji di dapatkan 6(60\%) responden yang gula darahnya normal dan 4 (40\%) respon yang gula darahnya tidak normal dari $10(100 \%)$ responden. Setelah pemberian air rebusan daun jambu biji 10 lembar selama 7 hari.

Berdasarkan hasil analisa dengan menggunakan uji Mc. Nemar maka diperoleh nilai signifikasi 0,031 yang berarti lebih kecil dari $\alpha=0,05$ yang berarti bahwa ada pengaruh yang bermakna antara glukosa darah sebelum pemberian air rebusan daun jambu biji terhadap kadar glukosa darah pada penderita diabetes mellitus tipe II di wilayah kerja Puskesmas Pekkabata Kabupaten Polewali Mandar.

\section{Saran}

Teoritis

Menambah referensi dan wawasan tentang pengaruh pemberian air rebusan daun jambu biji terhadap kadar glukosa darah pada penderita diabetes mellitus tipe II.

Praktis

Sebagai referensi yang dapat
digunakan sehingga dikembangkan untuk

selanjutnya tentang pengaruh pemberian air rebusan daun jambu biji terhadap kadar glukosa darah pada penderita diabetes mellitus tipe II. Sehinga hasil yang didapatkan dalam penelitian ini akan lebih bermanfaat untuk peneliti selanjutnya .

\section{DAFTAR PUSTAKA}

Maharani, Rosalina, S.Kp.,M.Kes, Puji Purwaningsih, S.Kep., Ns, 2013. JURNAL PENGARUH PEMBERIAN AIR REBUSAN DAUN JAMBU BIJI (PSIDIUM GUAJAVA) TERHADAP KADAR GLUKOSA DARAH PADA PENDERITA DIABETES MELLITUS TIPE II DI DESA LEYANGANKECAMATAN UNGARAN TIMUR KABUPATEN SEMARANG. Diakses tanggal 15 Januari 2016

Kunto Setyadi ,Rosalina, S.Kp., M.Kes , Tina Mawardika, S.Kep., Ns. 2012. JURNAL PENELITIAN PENGARUH TERAPI REBUSAN DAUN SIRIH MERAH (Piper crocatum) TERHADAP PENURUNAN KADAR GLUKOSA DARAH PADA LANSIA PENDERITA DIABETES MELITUS DI DESA CANDIREJO KECAMATAN UNGARAN BARAT. Diakses tanggal 15 Januari 2016

Suryono*, Sevin Yudha, Ds. Pandansari Purwoasri, 2012. JURNAL PENELITIAN EFEKTIFITAS DAUN SIRIH MERAH UNTUK MENURUNKAN KADAR GULA DARAH PADA PENDERITA DIABETES MELLITUS.Diakses tanggal 15 Januari 2016

Infodatin, Pusat dan Informasi Kementrian Kesehatan RI. Diakses tanggal 17 Januari 2016

Dian Putri, 2013. Artikel Pengaruh Konsentrasi Ekstrak Air Daun Sirih Merah terhadap Penurunan Kadar Gula Darah pada Mencit (Mus musculus ). Diakses tanggal 19 Januari 2016.

Aisyamasawi,2015.Artikel Pengaruh rebusan Daun Sirih Merah Terhadap Perubahan Kadar Gula Darah Klien Dengan Diabetes Melitus. Diakses tanggal 19 
Januari

2016.

Dari

www.kompasiana.com

Healthy Articles, 2012. Sirih Merah Turunkan Glukosa Darah

Diakses tanggal 20 Januari 2016.

Paul Lamanifak, 2012. Artikel JAMBU BIJI

DAN DAUN NYA DAPAT

MENGOBATI DIABETES. Diakses pada tanggal 20 januari 2016. Dari www.andasehat.com

Paul Apt, 2014. Karya Tulis Ilmiah : PEMANFAATAN DAUN JAMBU BIJI

Diakses tanggal 20 januari 2016.

Sutanto, 2010. CEKAL (Cekal dan Tangkal) Penyakit modern Hipertensi, stroke, jantung, kolesterol, dan diabetes.
Hery Seryoko, 2011. 25 Tanaman obat obat ampuh dabetes mallitus

Rr. CharlesFox , Dr. Anne Klivert 2010. Bersahabat dengan diabetes

Prof. Dr. H. Ahmad. Asdie, Sp.PD.KEMD, 2007. Diabetes

Alimul hidayat, A. Aziz. 2007. Metode Penelitian Keperawatan dan Teknik Analisa Data. Salemba Medika

Saryono, 2011. Metodologi Penelitian Kesehatan. Mitra Cindika Press. Yogyakarta

Notoadmotjo, 2012. Metodologi Penelitian Kesehatan. Edisi revisi. Cetakan kedua. Rineka cipta. Jakarta.

Dr. Budiman, S.Pd., SKM., S.Kep., M.Kes, 2013. Penelitian Kesehatan Buku Pertama . 